\title{
Assemblage of buried and seabed tunnel valleys in the central North Sea: from morphology to ice-sheet dynamics
}

\author{
M.A. STEWART ${ }^{1 *}$ \\ ${ }^{1}$ British Geological Survey, Murchison House, West Mains Road, Edinburgh, EH9 3AA \\ *Corresponding author (e-mail: mstewart@bgs.ac.uk)
}

Tunnel valleys are kilometre-scale, channel-like, incised subglacial landforms usually associated with glaciated lowlands (Ó Cofaigh 1996). Tunnel valleys related to the Pleistocene glaciations are present onshore and offshore of northwest Europe (Huuse \& Lykke-Andersen 2000; Van der Vegt et al. 2012). In the central North Sea, tunnel valleys are found buried in the Quaternary succession, and as bathymetric deeps at the seabed. 3D seismic data from the central North Sea image the extensive networks of buried tunnel valleys which consist of multiple generations of cross-cutting landforms (Stewart $e t$ al. 2013). The seabed tunnel valleys are identified in high-resolution bathymetric data, and form another set of younger glacial landforms. Morphological measurements of the buried and seabed tunnel valleys are compared to infer their relationship to past ice-margins and highlight the differences in ice-sheet configuration over time.

\section{Description}

In the central North Sea, over 180 buried tunnel valleys are clearly imaged within 14 overlapping 3D seismic data sets originally acquired for the hydrocarbon industry (Fig. 1a, Stewart et al. 2013). The survey area lies between $56^{\circ} \mathrm{N}$ and $59^{\circ} \mathrm{N}$ and $1^{\circ} \mathrm{W}$ to $2^{\circ} \mathrm{E}$, within water depths between $90 \mathrm{~m}$ and $150 \mathrm{~m}$. The buried tunnel valleys form part of the extensive erosive surface at the top of the Aberdeen Ground Formation, usually related to the Pleistocene glaciations of the region from the mid-Quaternary onwards (Stoker et al. 1985; Graham et al. 2011). The age of the buried valleys is constrained by their stratigraphic position above the Bruhnes-Matuyama magnetic reversal (found in a number of boreholes in the region and dated at $780 \pm 5$ ka B.P, Stoker $e t$ al. 1983), and below sediments dated to $30{ }^{14} \mathrm{C}$ ka B.P (Graham et al. 2010).

When mapped throughout the study area, the buried tunnel valleys appear to form complex inter-connected networks (Fig. 1b). In the higher-resolution 3D datasets (horizontal resolutions of 12.5-25 m, Fig. 1c), it is apparent that the buried tunnel valleys show stratigraphic and cross-cutting relationships which allow them to be separated into discreet generations of landforms. As each buried tunnel valley is identified within a single dataset (Fig 1d), the relative age of the valleys can be mapped out from oldest to youngest, as in Figure 1e (Stewart et al. 2013). In the northern part of the study area, where higher-resolution datasets were available, seven generations of buried tunnel valleys have been identified to a high degree of confidence over a region of $14,400 \mathrm{~km}^{2}$ (Fig. $2 \mathrm{a}$; Stewart et al. 2013). In the southern part of the study area, three generations of tunnel valleys were identified within one dataset (Fig. 2b).

Detailed morphological measurements, originally presented in Table 1 of Stewart et al. (2013), revealed that $96 \%$ of the buried tunnel valleys are between $300 \mathrm{~m}$ and $3000 \mathrm{~m}$ wide, with a few reaching $7.5 \mathrm{~km}$ in width. Maximum length within the study area was $117 \mathrm{~km}$, although it was clear that a number of tunnel valleys extend beyond the limits of the dataset (Fig. 1b). Many of the buried tunnel valleys also appear to start and/or stop abruptly with relatively short lengths of around 13-15 km (Fig. 2b i)..Some generations of buried tunnel valleys displayed statistically significant characteristic morphology; generation 1 and 2 tended to be narrower, shorter, and more v-shaped, while generation 4 tunnel valleys were particularly wide and shallow (Fig. $1 \mathrm{~g}$, 2a). Most individual tunnel valleys display a relatively straightforward, linear planform once separated into generations, although anastomosing valleys with inter-channel 'island' features were observed locally (Figs. 1f, 2b). Measurements of valley-wall steepness range between $5^{\circ}$ and $40^{\circ}$ and asymmetry between walls is common, although not apparently related to particular generations.

Most of the tunnel valleys display a significantly undulating basal profile, with along-slope angles between $1^{\circ}$ and $10^{\circ}$, sometimes reaching up to $30^{\circ}$ in areas of significant overdeepening (Stewart et al. 2013). The largest valleys average around $200 \mathrm{~m}$ in depth from shoulder to base; most of the buried valleys are between 80 and $180 \mathrm{~m}$ from shoulder to base.

Weighted orientation measurements, which take into account variation in directionality along length, are presented as rose diagrams with a mean orientation for each of the generations in Figure 2a-b. All orientation measurements are bi-directional, as there is no indication of flow direction for the buried tunnel valleys. In the northern part of the study area (Fig. 2a) generations 5, 6 and 7 do not show a preferred orientation; generations 1, 2, 3 and 4 display overall NE-SW or NNE-SSW preferred orientations with significant differences in orientation between each generation of buried tunnel valleys (see Table 4 of Stewart et al. 2013). In the southern part of the study area, the oldest generation (generation $1 \mathrm{M}$, Fig. 2b) trends NE-SW, but generations $2 \mathrm{M}$ and $3 \mathrm{M}$ trend NW-SE (Fig. 2b)

At the seafloor, tunnel valleys have been identified using the OLEX singlebeam echosounder bathymetric dataset (www.olex.no). OLEX data have vertical resolution of $1 \mathrm{~m}$ in water depths greater than $100 \mathrm{~m}$, and up to $10 \mathrm{~cm}$ where water depth is less than $100 \mathrm{~m}$. OLEX data can be gridded to provide a 3D surface where tunnel valleys are well-imaged as linear deeps (Fig. 2c). Horizontal resolution is dependent on line spacing; coverage is very good (up to $5 \mathrm{~m}$ ) in the northern part of the study area in the central North Sea (north of $58^{\circ} \mathrm{N}$ ) but less comprehensive in the southern part of the study area (Fig. $2 \mathrm{~d}, 2 \mathrm{e}$ ), where data gaps are more common.

Two sets of tunnel valleys are present as bathymetric deeps between $56^{\circ} \mathrm{N}, 2^{\circ} \mathrm{W}$ and $59^{\circ} 30^{\prime} \mathrm{N}, 2^{\circ} \mathrm{E}$ in water depths averaging between $90 \mathrm{~m}$ and $140 \mathrm{~m}$ (Fig. 1a). To the north, 21 distinct seabed tunnel valleys (referred to as the Fladden Group), are present between $58^{\circ} \mathrm{N}, 1^{\circ} 50^{\prime} \mathrm{W}$ and $59^{\circ} 35^{\prime} \mathrm{N}, 4^{\circ} \mathrm{E}$ (Fig. $1 \mathrm{a}, 2 \mathrm{~d}$ ). About $180 \mathrm{~km}$ south, thirteen tunnel valleys (referred to as the Devil's Hole Group) are discernible from OLEX data between $0^{\circ} 35^{\prime} \mathrm{W}, 57^{\circ} 10^{\prime} \mathrm{N}$ and $1^{\circ} 15^{\prime} \mathrm{E}$, $55^{\circ} 45^{\prime} \mathrm{N}$ (Fig. 2e). The valleys are preserved as bathymetric features on the seabed and are therefore considered to be related to the Last Glacial Maximum in the central North Sea, 25-30 ka B.P (Graham et al. 2011). No evidence was found for any cross-cutting relationships between the seabed tunnel valleys. Summary morphological measurements for the seabed tunnel valleys are shown in Figure $2 \mathrm{f}$. Average widths for the seabed tunnel valleys are $1.4 \mathrm{~km}$ for the Devil's Hole Group and $1.7 \mathrm{~km}$ for the Fladden Group, with one valley in Fladden measuring $7.7 \mathrm{~km}$ at its widest point. All of the seabed valleys appear to start and stop abruptly, with the longest reaching $63.9 \mathrm{~km}$ in the Fladden area (Fig. 2d). Average valley wall steepness measurements are around $5^{\circ}$, with maximum values up to $22.8^{\circ}$. Asymmetry in valley wall steepness is common; $56 \%$ of the incisions show a difference in slope angle between valley sides of more than one degree, and $48 \%$ more than two degrees. Both sets of tunnel valleys are relatively linear in planform, and although branching is visible at locations A and B in the Fladden Group (Fig. 2d) and X, Y and Z in Devil's Hole (Fig. 2e), no consistent branching direction is observed. Weighted orientation measurements reveal a general NNW-SSE trend for the Fladden Group and a N-S trend for the Devil's Hole Group, with mean orientations of $149^{\circ}$ and $179^{\circ}$, respectively. Both sets of seabed tunnel valleys show fairly regular spacing, and are distributed in an arcuate trend around the Witch Ground area (Fig. 2d).

The seabed tunnel valleys also have undulating basal profiles: the Fladden Group contains internal deeps of more than $70 \mathrm{~m}$ at angles of 
$7^{\circ}$ or more (Fig. $2 \mathrm{~g}$ ); the Devil's Hole Group shows variations of $90 \mathrm{~m}$ at angles up to $6^{\circ}$. The deepest point of the seabed tunnel valleys is within the Fladden Group at $290 \mathrm{~m}$ below sea-level, with a maximum internal depth (from shoulder to base of valley) of $150 \mathrm{~m}$.

\section{Interpretation}

The morphological measurements for both the buried and seabed tunnel valleys are consistent with those recorded for other tunnel valleys in the region (Huuse \& Lykke-Andersen, 2000; Van der Vegt et al. 2012). The undulating basal profiles observed throughout the tunnel valley analyses provide evidence for formation by meltwater under pressure and confirm the interpretation of the buried and seabed tunnel valleys as subglacial landforms (Fig. 2g; Stewart et al. 2013). Both the buried and seabed tunnel valleys are therefore considered to have been formed beneath ice-sheets which extended into the central North Sea multiple times during the Pleistocene glaciations. No major changes in substrate or topography are present within the study area in the central North Sea; thus, changes in tunnel valley morphology and orientation are interpreted to reflect variations in ice-sheet dynamics that affected their formation during multiple episodes of glaciation.

The morphological measurements for the buried tunnel valleys reveal that valley geometries are sometimes linked to particular generations. The narrower, vshaped, regularly spaced tunnel valleys of generation 1 (Fig. 2a) may relate to relatively rapid incision and fill, thus preserving a narrow, steep channel geometry (Stewart et al. 2013). The wide, shallow valleys of generation 4 (Fig. 2b) may be a result of direct ice contact or migration of an internal channel during formation, as discussed in Stewart et al. (2013), or re-occupation of older tunnel valleys. Fig. 1d shows the wide tunnel valley $\mathrm{m}$ (in red), which appears to follow the curve of the Generation 3 tunnel valleys i, j and k. The profile a-a' (Fig. 1g) demonstrates the relationship with the older valleys, and with the younger valley o.

Morphological measurements of width, length, valley-wall steepness and planform geometry for the seabed tunnel valleys are comparable to the buried valleys; it is considered likely that they formed as a result of similar subglacial processes, but at different times. The lack of cross-cutting is used to interpret the seabed tunnel valleys as one 'generation' when compared to the buried valleys.

As tunnel valleys are considered to form roughly perpendicular to ice-sheet margins during deglaciation, orientation measurements for the tunnel valleys are used to infer approximate ice-flow direction (Huuse \& Lykke-Andersen 2000; Van der Vegt et al. 2013). For the buried tunnel valleys, changes in orientation are apparent between generations and between those valleys in the north (Fig. 2a) and the south (Fig. 2b) of the study area. Differences in orientation between generation imply changes in ice-sheet dynamics between episodes of tunnel valley incision. Most of the buried tunnel valleys to the north trend approximately NE-SW, and are considered to relate to ice retreat towards the UK mainland (Stewart et al. 2013). The NW-SE trending valleys in the southern part of the study area (Fig. 2b) can also be related to ice retreat towards the UK, but, due to the change in directionality and distance from the UK, the generation 1M valleys (Fig. 2b) are interpreted to reflect the influence of Scandinavian ice, possibly retreating towards the NE (Stewart et al. 2013). Lack of chronological control prevents the correlation of the generations between the northern and southern parts of the central North Sea.

The difference in orientation between the buried and seabed tunnel valleys is shown in Figure $2 \mathrm{~h}$, where the buried valleys and their mean orientations are outlined in black with black arrows, and the seabed tunnel valleys are in red, all superimposed upon the OLEX bathymetric dataset for the central North Sea.

\section{Discussion}

The buried and seabed tunnel valleys of the central North Sea form an assemblage of subglacial landforms that reflects the history of glaciation in the region from the mid-Quaternary until the LGM. Apparently complex networks comprise multiple generations of superimposed tunnel valleys with characteristic variations in morphology and orientation.

The orientations of the seabed tunnel valleys are significantly different than those of the older buried tunnel valleys, with a strong NNW-SSE or N-S trend (Fig. 2d, 2e). N-S trending tunnel valleys at the seabed indicate formation parallel to an E-W trending ice-margin, the geometry of which is difficult to envisage in the central North Sea; most models rely on a build up of ice on the UK and Scandinavian margins with an approximate N-S trend for the icesheet termini, as supported by evidence from other landform assemblages such as seabed moraines (Bradwell et al. 2007; Clark et al. 2012).

Given the approximately N-S trend of the seabed tunnel valleys, and their radial pattern around the Witch Ground Basin area (where no open tunnel valleys are present at the seabed), a schematic model of formation is proposed where the seabed tunnel valleys formed in response to LGM ice-sheet breakup driven by a marine incursion from the east which developed into an embayment (dashed line in Fig. 2h), as suggested by Bradwell et al. (2008) and supported by Clark et al. (2012). In such a scenario, the Fladden Ground incisions would be draining towards the south, and the Devil's Hole towards the North. The marine incursion would derive from the east or northeast - possibly along the Norwegian Channel area (Sejrup et al. 2009) and then into the Witch Ground. In contrast, the buried channels reflect the breakup of older, pre-LGM ice-sheets by a N-S 'unzipping' of the Scandinavian and UK ice-sheets, and their retreat towards the mainland.

\section{References}

BRADWELL, T., STOKER, M., et al. 2008. The northern sector of the last British Ice Sheet: maximum extent and demise. Earth Science Reviews, 88, 207226.

CLARK, C. D., HUGHES, A. L. C., GREENWOOD, S. L., JORDAN, C. \& SEJRUP, H. P., 2012. Pattern and timing of retreat of the last British-Irish Ice Sheet. Quaternary Science Reviews, 44, 112-146.

GRAHAM, A., STOKER, M. S., LONERGAN, L., BRADWELL, T. \& STEWART, M., 2011. The Pleistocene glaciations of the North Sea Basin. In Ehlers, J., Gibbard, P.L., \& Hughes, P.D., (eds.), Quaternary Glaciations: Extent and Chronology: a Closer Look. Elsevier, 261-278.

GRAHAM, A. G. C., LONERGAN, L. \& STOKER, M. S. 2010. Depositional environments and chronology of late Weichselian glaciation and deglaciation in the central North Sea. Boreas, 39, 471-491.

HUUSE, M. \& LYKKE-ANDERSEN, H. 2000. Overdeepened Quaternary valleys in the eastern Danish North Sea: morphology and origin. Quaternary Science Reviews 19, 1233-1253

Ó COFAIGH, C. 1996. Tunnel valley genesis. Progress in Physical Geography, 20, 1-19.

STEWART, M. A., LONERGAN, L. L. \& HAMPSON, G. H. 2012. 3D seismic analysis of buried tunnel valleys in the central North Sea: morphology, cross-cutting generations and glacial history. Quaternary Science Reviews, 72, 1-17.

STOKER, M. S., SKINNER, A. C., FYFE, J. A. \& LONG, D. 1983. Palaeomagnetic evidence for early Pleistocene in the central and northern North Sea. Nature, 304, 332-334.

VAN DER VEGT, P., JANSZEN, A. \& MOSCARIELLO, A. 2012. Tunnel Valleys: current knowledge and future perspectives. In Huuse, M., Redfern, J., Le Heron, D.P., Dixon, R.J., Moscariello, A., Craig, J., (eds.), Glaciogenic Reservoirs and Hydrocarbon Systems. Geological Society Special Publication, 368, 75-97. 

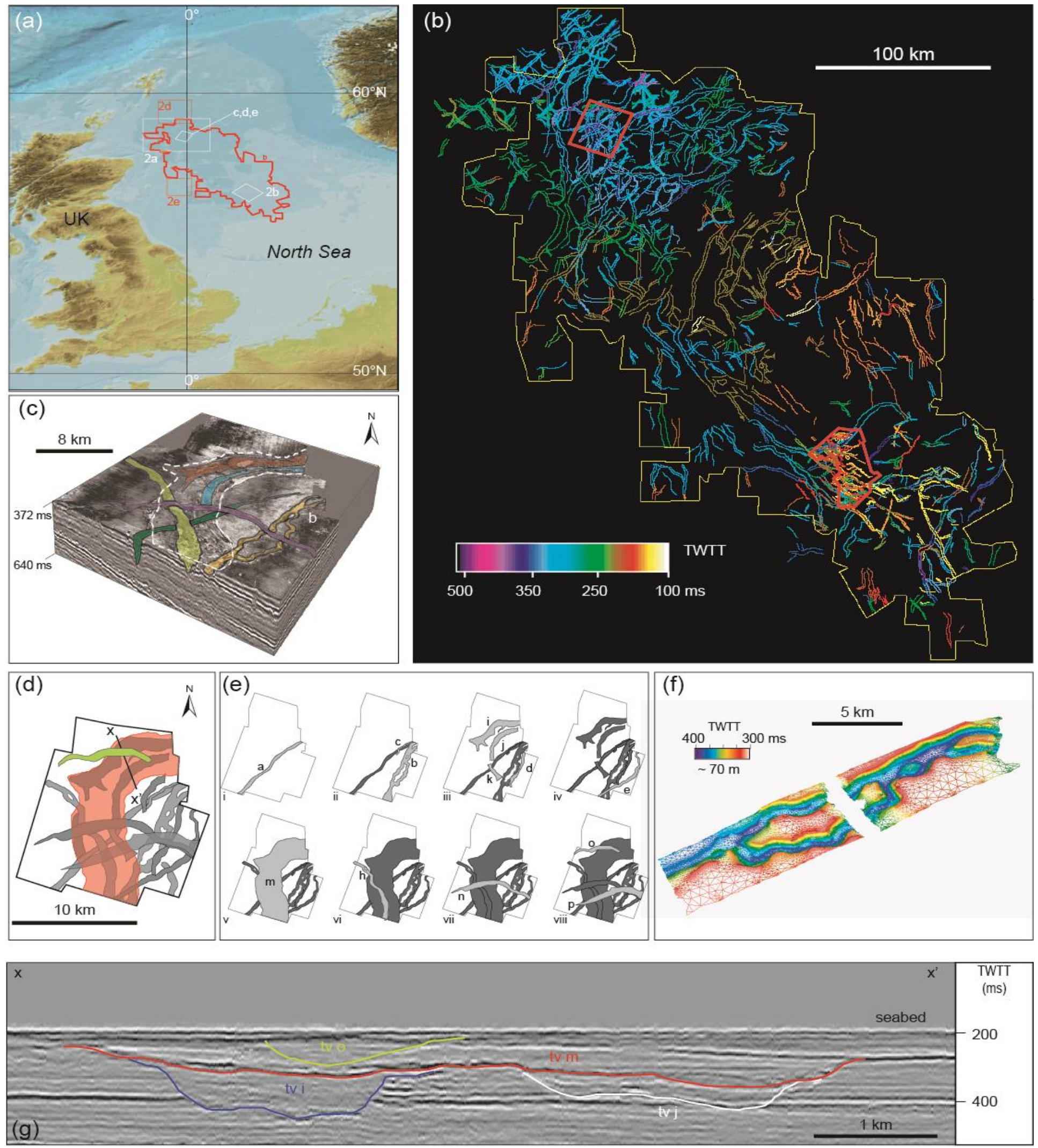

Figure 1(a) Location of study area, 3D seismic volumes and examples in central North Sea. Map from GEBCO v 8.0. (b) All tunnel valley outlines mapped within 3D seismic data in the study area where colour indicates two way travel time (TWTT) in milliseconds. (c) 3D seismic volume showing cross-cutting examples of tunnel valleys. For location see Fig. 1a. (d) All tunnel valleys identified within one 3D seismic volume. For location see Fig. 1a. (e) Eight generations of buried tunnel valleys separated out from 3D seismic volume. For location see Fig. 1a. (f) Anastomosing tunnel valley surface interpreted from 3D seismic volume. Location b in Fig. 1c. (g) Profile a-a' showing the wide, shallow valley $\mathrm{m}$ which appears to re-occupy the older tunnel valleys $\mathrm{i}$ and $\mathrm{j}$, and is cross-cut by tunnel valley $\mathrm{o}$. For locations see Fig. 1c and 1d. 

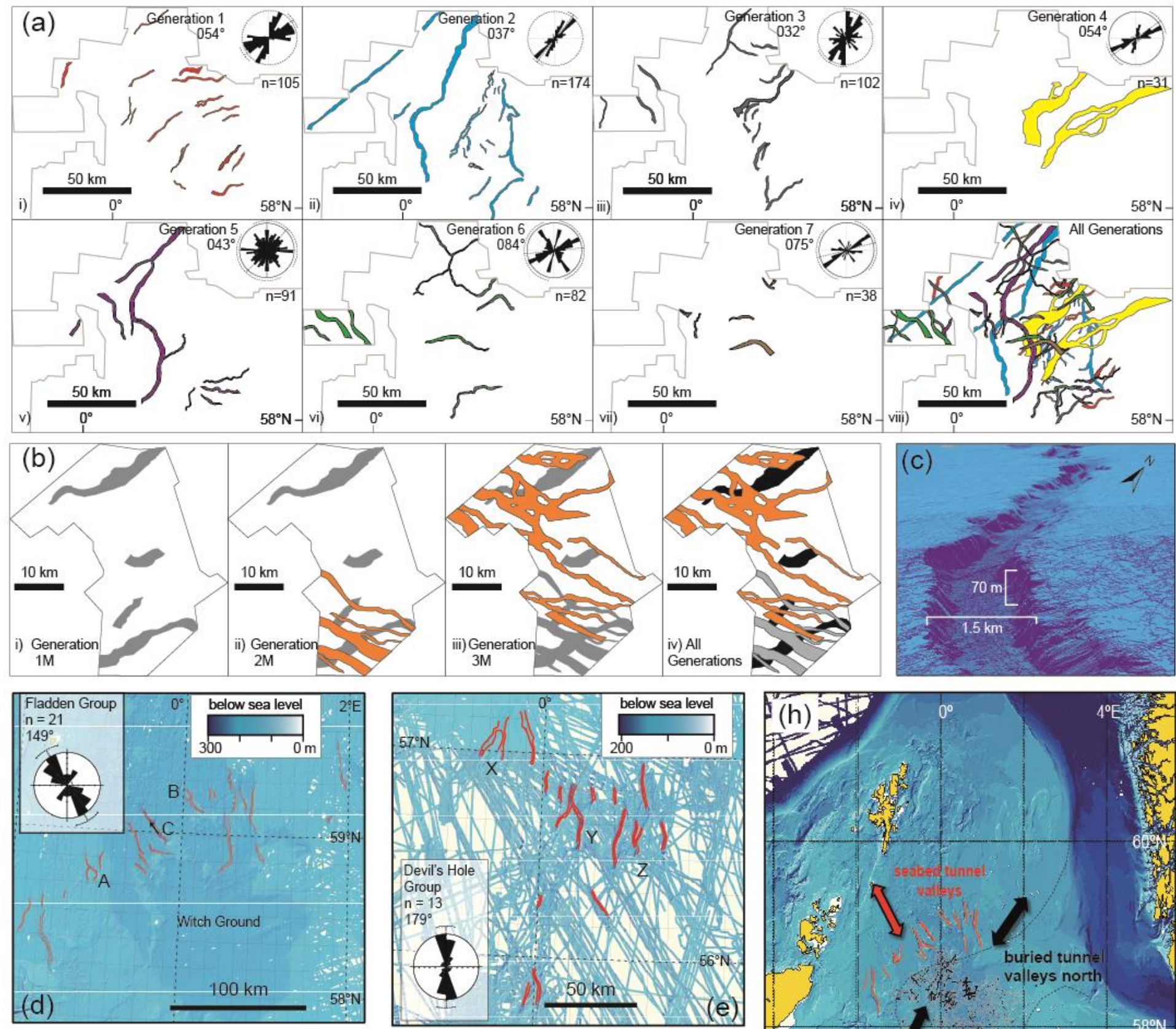

\begin{tabular}{|l|c|c|}
\hline$(\mathrm{f})$ & $\begin{array}{l}\text { Devil's } \\
\text { Hole }\end{array}$ & Fladden \\
\hline Average width $(\mathrm{m})$ & 1.4 & 1.7 \\
\hline Max Width $(\mathrm{km})$ & 2.3 & 7.7 \\
\hline Min Width $(\mathrm{km})$ & 0.6 & 0.6 \\
\hline Average length $(\mathrm{km})$ & 24.7 & 28.1 \\
\hline Max length $(\mathrm{km})$ & 39.4 & 63.9 \\
\hline Min length $(\mathrm{km})$ & 12.8 & 7.0 \\
\hline Average sinousity & 1.0 & 1.2 \\
\hline Average wall steepness & $5.4^{\circ}$ & $4.1^{\circ}$ \\
\hline Max wall steepness & $22.8^{\circ}$ & $14.5^{\circ}$ \\
\hline Min Wall steepness & $0.4^{\circ}$ & $0.6^{\circ}$ \\
\hline
\end{tabular}
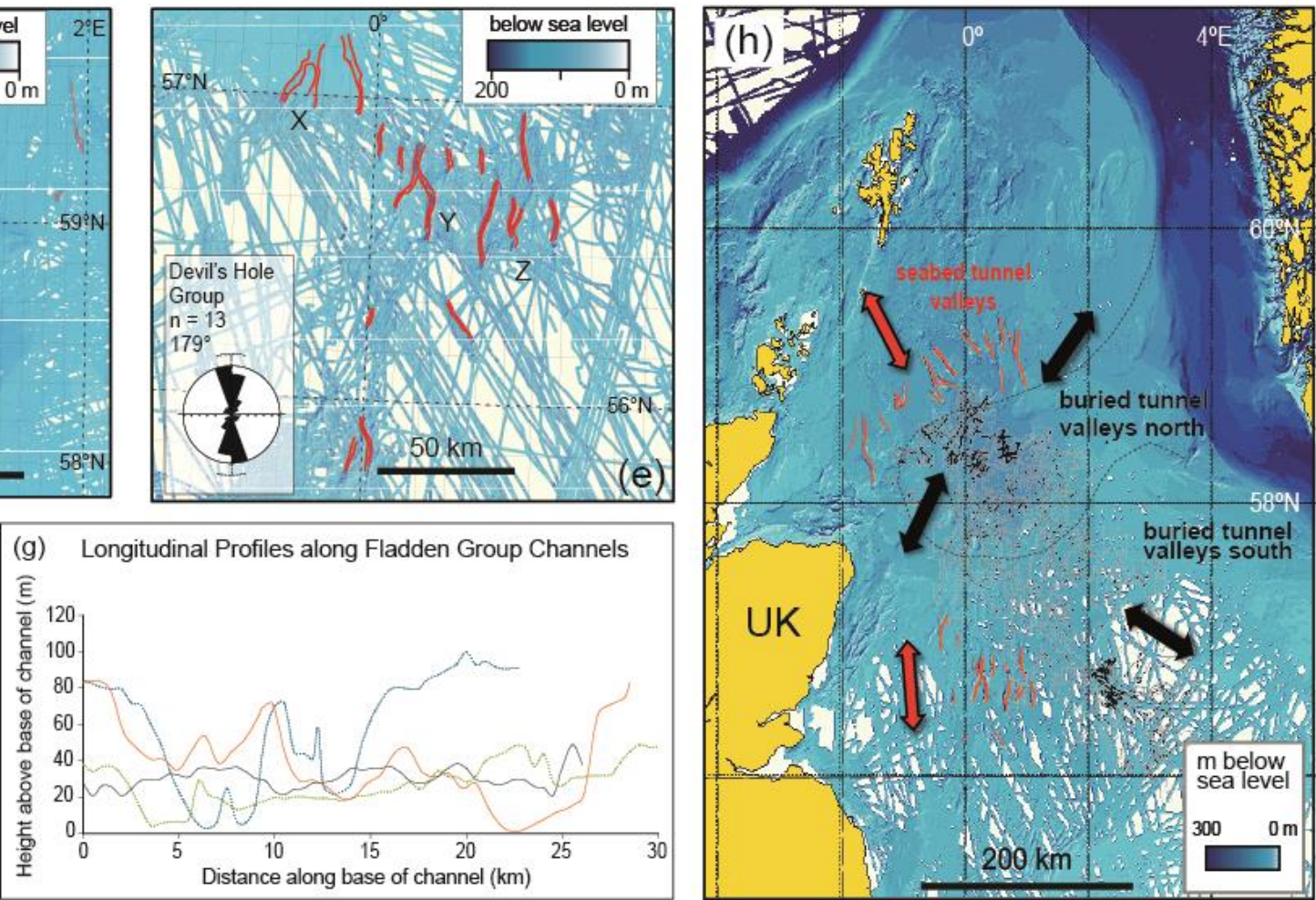

Fig. 2. (a) Seven generations of tunnel valleys from oldest (i) to youngest (vii), adapted from Stewart et al. 2013. (b) Three generations of tunnel valleys from oldest (1M) to youngest (3M), adapted from Stewart et al. 2013. (c) Oblique view to the north-west along seabed tunnel valley in OLEX dataset. Location C in Figure 2d. VE x 8. Linear features on the seabed are acquisition artefacts. Acquisition single-beam echo-sounder. Grid-cell size $5 \mathrm{~m}$. (d) Fladden Group seabed tunnel valleys in the OLEX dataset outlined in red with weighted orientation measurements including mean orientation. (e) Devil's Hole Group seabed tunnel valleys in the OLEX dataset outlined in red with weighted orientation measurements including mean orientation. (f) Summary morphological measurements for seabed tunnel valleys. (g) Longitudinal profile along five tunnel valleys in the Fladden Group showing undulating basal profiles and overdepeened sections. (h) Mean orientation measurements of seabed tunnel valleys (red) and buried tunnel valleys (black) in the central North Sea superimposed on the OLEX dataset. Position of proposed embayment in the LGM ice margin is shown as a dashed line. Panels (a), (b) and (d) located in Fig. 1a. 